\title{
Nemoci motorických neuronů
}

\section{MUDr. Radim Mazanec, Ph.D. - editor hlavního tématu Neurologická klinika 2. LF UK a FN Motol, Praha}

Nemoci motorických neuronů jsou charakterizované selektivním postižením centrálních nebo periferních motoneuronů nebo jejich kombinovaným postižením. Historie je spojená se jmény Jeana Marie Charcota, Alfreda Vulpiana, Williama Kennedyho, ale i se jmény slavných nemocných jako byl Lou Gehrig nebo jakým je astrofyzik Stephen Hawking. Představují relativně vzácnou a výrazně heterogenní skupinu chorob s různými patogenetickými mechanizmy, klinickými projevy, terapeutickými možnostmi a různou prognózou. Vyskytují se v dětství i v dospělosti a jejich prríčiny mohou být vrozené i získané.

Nemoci motorických neuronů vzbuzovaly $\checkmark$ mnoha generacích neurologů na jedné straně obavy a respekt pro svou závažnost a na druhé straně jsou velkou výzvou pro vědecké týmy na celém světě. Uplynulých 25 let přineslo nové a zásadní poznatky jak v oblasti neurogenetiky (odhalení genetických př́čin i nových patogenetických mechanizmů zániku motoneuronů), tak v oblasti neuroimunologie (autoimunitní mechanizmy např. multifokální motorické neuropatie). Nepochybně zajímavou informaci o nových mechanizmech neurodegenerace poskytují aktuální poznatky o TDP43 proteinopatiích jako event. kontinuu mezi amyotrofickou laterální sklerózou a frontotemporální demencí.

Cílem hlavního tématu je poskytnout prehledné informace o nových poznatcích u několika vybraných nosologických jednotek, které mají největší význam pro klinickou praxi v populaci dětských i dospělých pacientů. Čtenář by měl získat přehled o klinických symptomech, diagnostických postupech a možnostech léčby tak, aby je ve své klinické praxi dokázal včas rozpoznat a navrhl správný postup, odpovídající úrovni poznatků v roce 2016, nebot’ od posledního uceleného čísla Neurologie pro praxi, které bylo věnováno tomuto tématu, letos uplynulo právě deset let.

Děkuji autorům všech príspěvků za jejich úsilí a čas, který věnovali přípravě manuskriptů, a pomohli tak vytvořit odborný materiál na vysoké odborné i edukační úrovni. 